\title{
Rhizosphere heterogeneity shapes abundance and activity of sulfur-oxidizing bacteria in vegetated salt marsh sediments
}

\author{
François Thomas ${ }^{1 *}{ }^{+}$, Anne E. Giblin ${ }^{2}$, Zoe G. Cardon ${ }^{2}$ and Stefan M. Sievert ${ }^{1 *}$
}

${ }^{1}$ Watson Laboratory, Biology Department, Woods Hole Oceanographic Institution, Woods Hole, MA, USA

${ }^{2}$ Marine Biological Laboratory, The Ecosystems Center, Woods Hole, MA, USA

\section{Edited by:}

Rich Boden, University of Plymouth, UK

Reviewed by:

Joana Falcão Salles, University of Groningen, Netherlands

Dimitry Y. Sorokin, Delft University

of Technology, Netherlands

*Correspondence:

François Thomas, LIEC UMR7360

CNRS-Université de Lorraine,

BP70239 54506 Vandoeuvre-les-

Nancy, France

e-mail: francois.thomas@

univ-lorraine.fr;

Stefan M. Sievert, Biology

Department, Woods Hole

Oceanographic Institution, 360

Woods Hole Road MS\#52, Woods

Hole, MA 02543, USA

e-mail: ssievert@whoi.edu

${ }^{\dagger}$ Present address:

François Thomas, Laboratoire Interdisciplinaire des

Environnements Continentaux, UMR7360 CNRS-Université de

Lorraine, Vandoeuvre-les-Nancy, France
Salt marshes are highly productive ecosystems hosting an intense sulfur (S) cycle, yet little is known about S-oxidizing microorganisms in these ecosystems. Here, we studied the diversity and transcriptional activity of S-oxidizers in salt marsh sediments colonized by the plant Spartina alterniflora, and assessed variations with sediment depth and small-scale compartments within the rhizosphere. We combined next-generation amplicon sequencing of $16 \mathrm{~S}$ rDNA and rRNA libraries with phylogenetic analyses of marker genes for two S-oxidation pathways (soxB and rdsrAB). Gene and transcript numbers of soxB and rdsrAB phylotypes were quantified simultaneously, using newly designed (RT)-qPCR assays. We identified a diverse assemblage of S-oxidizers, with Chromatiales and Thiotrichales being dominant. The detection of transcripts from S-oxidizers was mostly confined to the upper $5 \mathrm{~cm}$ sediments, following the expected distribution of root biomass. A common pool of species dominated by Gammaproteobacteria transcribed S-oxidation genes across roots, rhizosphere, and surrounding sediment compartments, with rdsrAB transcripts prevailing over soxB. However, the root environment fine-tuned the abundance and transcriptional activity of the S-oxidizing community. In particular, the global transcription of soxB was higher on the roots compared to mix and rhizosphere samples. Furthermore, the contribution of Epsilonproteobacteria-related S-oxidizers tended to increase on Spartina roots compared to surrounding sediments. These data shed light on the under-studied oxidative part of the sulfur cycle in salt marsh sediments and indicate small-scale heterogeneities are important factors shaping abundance and potential activity of S-oxidizers in the rhizosphere.

Keywords: rdsrAB, rhizosphere, salt marsh, soxB, sulfur oxidation, Spartina alterniflora

\section{INTRODUCTION}

Salt marshes are highly productive coastal ecosystems found in intertidal areas and vegetated by salt tolerant non-woody plants. Along the Atlantic coast of the United States, the cord grass Spartina alterniflora is typically the dominant plant in areas that are submerged for part of each tidal cycle (Niering and Warren, 1980). Rates of net primary production by S. alterniflora are extremely high, ranging from 460 to $3200 \mathrm{~g} \mathrm{~cm}^{-2}$.year ${ }^{-1}$, much of which occurs belowground (Schubauer and Hopkinson, 1984; Giblin and Wieder, 1992). The high concentration of organic matter produced either by the decay of plant tissues or leakage of dissolved compounds from the root system, fuels aerobic respiration and, together with frequent waterlogging, leads to oxygen depletion in the sediments. Thus, abundant residual organic matter is available for anaerobic respiration through sulfate reduction. Consequently, rates of sulfate reduction in salt marshes are among the highest reported in the marine environment (Howarth and Hobbie, 1982; Hines et al., 1989; Laverman et al., 2012). The sulfide produced by sulfate reduction still contains much of the photochemical energy that was initially captured by plants into carbon-carbon bonds, making it potentially available to organisms collectively known as sulfur-oxidizers (S-oxidizers), completing the sulfur cycle (Howarth and Teal, 1980).

Sulfate-reducing prokaryotes have previously been extensively studied in salt marsh systems and were found to be generally dominated by Deltaproteobacteria, in particular members of the family Desulfobacteraceae and Desulfobulbaceae (Devereux et al., 1996; Klepac-Ceraj et al., 2004; Bahr et al., 2005). In contrast very little is known about the organisms carrying out S-oxidation in salt marshes. To date, S-oxidizers are known dominantly from environments such as hydrothermal vents, brines and nonvegetated coastal sediments (Robertson and Kuenen, 2006; Sievert et al., 2007; Ghosh and Dam, 2009). Only a few S-oxidizers have been cultivated from salt marshes, such as Thiovulum (Wirsen and Jannasch, 1978), Beggiatoa (Nelson et al., 1982) and Candidatus Arcobacter sulfidicus (Wirsen et al., 2002). In neutrophilic S-oxidizers, two distinct sulfur oxidation pathways involving different enzymes exist. Through the multi-enzyme SOX complex composed of SoxYZ, SoxXA, SoxB, and SoxCD, reduced sulfur compounds are completely oxidized to sulfate 
(Kelly et al., 1997; Friedrich et al., 2001). Alternatively, bacteria lacking the SoxCD component use the branched thiosulfate oxidation pathway, whereby sulfur accumulates as an intermediate and is sequentially oxidized to sulfite and sulfate by a reverse acting dissimilatory sulfite reductase (rDSR), an APS reductase and an ATP sulfurylase (Pott and Dahl, 1998; Kappler and Dahl, 2001). Genes involved in these two pathways have been used as functional markers to study the diversity and distribution of S-oxidizers in the environment, namely soxB (Petri et al., 2001; Meyer et al., 2007; Akerman et al., 2013), rdsrAB (Loy et al., 2009; Lenk et al., 2011) and aprA (Meyer and Kuever, 2007).

Many S-oxidizers are autotrophs or facultative autotrophs. They can couple S-oxidation to carbon fixation, therefore releasing the energy trapped in sulfide or other reduced sulfur compounds and producing labile organic matter that can fuel higher trophic levels. The lower concentrations of sulfide often reported from various salt marshes compared to subtidal sediments (Giblin and Howarth, 1984) suggest high rates of sulfide turnover, which may be enabled by a tight interaction between the microorganisms and the plants. Oxygen can diffuse out of plant roots into the sediment (Holmer et al., 2002), where S-oxidizers colonizing the rhizosphere may use it as a terminal electron acceptor. This interaction could benefit the plant by removing hydrogen sulfide, which is known to inhibit plant growth (Joshi and Hollis, 1977; Bradley and Morris, 1990; Pezeshki and Delaune, 1996). Alternatively, S-oxidizers can use nitrate as the electron acceptor and produce either $\mathrm{N}_{2}$ via denitrification or $\mathrm{NH}_{4}^{+}$via dissimilatory nitrate reduction to ammonium (Timmer-Ten Hoor, 1975; Brunet and Garcia-Gil, 1996; Otte et al., 1999; Sayama et al., 2005; Burgin and Hamilton, 2007) potentially affecting the fate of nitrate in eutrophic systems. Thus, the salt marsh rhizosphere is a dynamic, metabolically active environment featuring a variety of contrasted small-scale compartments where microorganisms involved in reductive and oxidative portions of S-cycling can co-exist and couple S-cycling with nitrogen and carbon cycling.

The present study investigates bacterial communities of S-oxidizers in sediments colonized by the dominant plant S. alterniflora in a New England salt marsh. We studied how smallscale heterogeneities across the vegetated sediment affect the diversity, distribution, and transcriptional activity of S-oxidizers. Specifically, we hypothesized that the rhizosphere or rhizoplane would represent an area of enhanced activity compared to bulk sediment due to a higher availability of electron acceptors to support the oxidation of reduced sulfur compounds and the possible interactions between S-oxidizers and sulfate-reducers, which have been shown to be stimulated by the release of dissolved organic matter from the roots. We further hypothesized that S-oxidizers known to be adapted to higher oxygen concentrations, like Gammaproteobacteria, would be found predominantly closer to the roots, while S-oxidizers known to be adapted to lower oxygen concentrations, like Epsilonproteobacteria, would be found further away. Samples were taken at two sites selected for their different flooding and salinity regimes. At each site, we collected rhizosphere and root samples separately in addition to bulk sediment samples. To characterize the S-oxidizers, we combined amplicon sequencing of $16 \mathrm{~S}$ rDNA and rRNA libraries with phylogenetic analyses of marker genes for two S-oxidation pathways (sox $\mathrm{B}$ and $r d s r \mathrm{AB}$ ). The abundance and transcriptional activity of the S-oxidizers identified were then quantified using newly designed (RT)-qPCR assays for the sox $\mathrm{B}$ and $r d s r \mathrm{AB}$ genes.

\section{MATERIALS AND METHODS SITE DESCRIPTIONS}

Samples were collected from two locations vegetated with S. alterniflora, selected for contrasting flooding and salinity regimes. The sites were $1.5 \mathrm{~km}$ apart along the Rowley River (Massachusetts, USA) at Plum Island Ecosystems Long-Term Ecological Research (PIE-LTER). Samples from Site 1 (N $42^{\circ} 43^{\prime}$ $32.04^{\prime \prime}$, W $70^{\circ} 51^{\prime} 19.91^{\prime \prime}$ ) were taken at the creekbank, characterized by more frequent and longer tidal flushing than the second site. Samples from Site $2\left(\mathrm{~N} 42^{\circ} 43^{\prime} 56.92^{\prime \prime}\right.$, W $\left.70^{\circ} 50^{\prime} 26.18^{\prime \prime}\right)$, which was further downstream, were collected on the marsh platform $9 \mathrm{~m}$ from the creekbank. Salinities at Site 2 during a typical summer range from 28-32 psu and show little variation over the tidal cycle. Salinities vary more at the Site 1 and range from 23 to 31 psu.

\section{SAMPLE COLLECTION}

For the investigation of bacterial diversity and transcriptional activity with depth in sediment, one core (polycarbonate core liner, $9 \mathrm{~cm}$ diameter, $30 \mathrm{~cm}$ length) was retrieved from Site 2 during July 2012, and subsampled at depth intervals of $2 \mathrm{~cm}$ (from 0 to $20 \mathrm{~cm}$ ) within $2 \mathrm{~h}$. Two grams of sediment/root mixture from each depth (hereafter referred to as "mix" samples) were transferred to a sterile tube containing $6 \mathrm{ml}$ of LifeGuard (MO-BIO, Carlsbad, CA). For the exploration of diversity and transcriptional activity on and around roots, we collected three cores at Site 1 and three at Site 2 in October of 2012. Cores were taken $50 \mathrm{~cm}$ apart. Within 2 h, "mix," "rhizosphere" and "roots" subsamples were taken from each core, at $5 \mathrm{~cm}$ depth. "Mix" samples were similar to those taken in July. Rhizosphere samples were gathered by separating roots from the remaining sediment with tweezers and gently shaking them in LifeGuard, releasing adhered "rhizosphere" sediment $(0.2-1 \mathrm{~g})$. Shaken roots were transferred to another tube containing LifeGuard, resulting in the "roots" sample $(0.2-0.5 \mathrm{~g})$. All samples were frozen on dry ice and stored at $-20^{\circ} \mathrm{C}$. To minimize bias, the same manipulator performed all sampling and root-sediment separation procedures.

\section{NUCLEIC ACID EXTRACTION AND cDNA SYNTHESIS}

RNA and DNA were extracted simultaneously using the RNA PowerSoil Total RNA Isolation and DNA Elution Accessory kits (MO-BIO) following the manufacturer's instructions for "mix" and "rhizosphere" samples. For consistency, the same kits were used to extract RNA and DNA from "roots" samples, placing the intact roots in the bead beating tubes. DNA was further purified using the PowerClean DNA Clean-Up kit (MO-BIO). RNA was digested for $30 \mathrm{~min}$ at $37^{\circ} \mathrm{C}$ with 2 units of TURBO-DNase (Ambion, Austin, TX) and purified using the RNeasy MinElute Cleanup kit (Qiagen, Valencia, CA). Reverse-transcription reactions were performed on $800 \mathrm{ng}$ ( $\mathrm{mix}$ and rhizosphere samples) or $400 \mathrm{ng}$ (roots samples) of total RNA using the DyNAmo cDNA Synthesis kit (Thermo Scientific). No-RT control reactions including all components except for the reverse transcriptase were 
prepared for each sample. cDNA synthesis was checked by PCR using bacterial 16S rRNA gene primers S-D-Bact-0341-a-S-17 and S-D-Bact-0515-a-A-19 (Klindworth et al., 2012). No PCR products were detected for similar reactions with no-RT controls, confirming the absence of gDNA contamination.

\section{ILLUMINA TAG SEQUENCING AND ANALYSIS}

Amplicon libraries were produced from DNA and cDNA fractions for all eighteen October samples, and five of the ten July samples (distributed from surface to depth). The V6 region of $16 \mathrm{~S}$ rRNA genes was amplified using previously reported primers designed for bacteria (Huber et al., 2007). Triplicate PCR reactions were conducted on $25 \mathrm{ng}$ of template in a final volume of $25 \mu \mathrm{l}$, containing $2 \mathrm{mM} \mathrm{MgSO}_{4}, 0.2 \mathrm{mM}$ dNTPs, $0.4 \mu \mathrm{M}$ of each primer, $1 \mathrm{X}$ Hi-Fidelity buffer and $2 \mathrm{U}$ of Platinum Taq HiFidelity Polymerase (Life Technologies, Carlsbad, CA). Reactions were denatured for $3 \mathrm{~min}$ at $94^{\circ} \mathrm{C}$, followed by 25 cycles of $30 \mathrm{~s}$ at $94^{\circ} \mathrm{C}, 45 \mathrm{~s}$ at $60^{\circ} \mathrm{C}$ and $1 \mathrm{~min}$ at $72^{\circ} \mathrm{C}$, and a final extension of $2 \mathrm{~min}$ at $72^{\circ} \mathrm{C}$. Triplicate reactions were pooled and purified using a Qiaquick PCR 96-well PCR clean-up plate or MinElute kit (Qiagen, Valencia CA). A second run of PCR (5 cycles) was performed on $8 \mu \mathrm{l}$ of purified products with fusion primers including indices and barcodes compatible with the Illumina HiSeq1000 platform (Eren et al., 2013).

After quantification by Picogreen assay (Life Technologies), $25 \mathrm{ng}$ of products were pooled and size selected (210-240 bp) on a $2 \%$ agarose PippinPrep cassette. The libraries were cleaned using MinElute kits and sequenced at MBL (Woods Hole, MA) in a single paired-end lane of Illumina. Completely overlapping paired-end reads were kept for further analysis (Eren et al., 2013). Quality-filtered reads are available through VAMPS (http:// vamps.mbl.edu) (project FRT_PIE1_Bv6). Sequences were clustered at 97\% similarity using usearch (Edgar, 2010). Taxonomy was assigned to each Operational Taxonomic Unit (OTU) using GAST (Huse et al., 2008) with a version of the Greengenes 13_5 database (McDonald et al., 2012) trimmed to the V6 region. OTUs were analyzed with QIIME v1.7 (Caporaso et al., 2010) and the R package phyloseq (McMurdie and Holmes, 2013). Data sets were rarefied to the lowest number of sequences per sample (142,916 reads). Bray-Curtis distance was used for Principal Coordinates Analysis (PCoA) on a relative abundance matrix comprising all OTUs belonging to the orders listed in Table 1. LEfSe (Segata et al., 2011) was used on the same matrix to determine indicator bacterial groups with a logarithmic linear discriminant analysis (LDA) score threshold of 2 .

\section{soxB AND rdsrAB CLONE LIBRARIES}

Amplification of $s o x \mathrm{~B}$ and $r d s r \mathrm{AB}$ genes were performed on $1 \mathrm{ng}$ of DNA from "mix" samples collected in July 2012. soxB fragments $(\sim 1020 \mathrm{bp})$ were amplified with the primers soxB432F and soxB1446B, using a previously described two-step PCR (Petri et al., 2001). Reactions contained $2.5 \mathrm{mM} \mathrm{MgCl}_{2}, 0.2 \mathrm{mM}$ of each dNTP, $1 \mu \mathrm{M}$ of each primer, $0.3 \mathrm{mM}$ BSA, 10\% DMSO and $0.5 \mathrm{U}$ of Taq DNA polymerase (Promega). The primers sox $527 \mathrm{~F}$ and sox1198R were used to specifically amplify soxB fragments from Epsilonproteobacteria ( $\sim 672 \mathrm{bp})$ as described previously (Akerman et al., 2013). Reactions contained $2.5 \mathrm{mM} \mathrm{MgCl}_{2}$,
$0.2 \mathrm{mM}$ of each dNTP, $0.6 \mu \mathrm{M}$ of each primer and $0.5 \mathrm{U}$ of Taq DNA polymerase. $r d s r \mathrm{AB}$ gene fragments $(\sim 2 \mathrm{~kb})$ were amplified using the primers rDSRA240F and rDSRB808R as described previously (Lenk et al., 2011). PCR reactions contained $1.5 \mathrm{mM}$ $\mathrm{MgCl}_{2}, 0.25 \mathrm{mM}$ of each dNTP, $2 \mu \mathrm{M}$ of each primer and $0.5 \mathrm{U}$ of Taq DNA polymerase. For each depth and primer set, triplicate reactions $(15 \mu \mathrm{l})$ were pooled and analyzed by $1 \%$ agarose gel electrophoresis. Bands of the expected size were excised and purified using the Qiaquick Gel Extraction Kit. Products from all depths were pooled, cloned using the TOPO-TA cloning kit for sequencing (Invitrogen, Carlsbad, CA) and sequenced by Beckman Coulter Genomics. An internal primer DSR874F was used for sequencing the internal part of the $2 \mathrm{~kb} r d s r \mathrm{AB}$ fragment (Loy et al., 2009). Sequences were checked with Sequencher 5.0.1 (Gene Codes Corporation, Ann Arbor, MI), translated into amino acid sequences and clustered into 90\% identity OTUs using the program CD-HIT (Huang et al., 2010). Alignments were generated with MAFFT (Katoh, 2002) and refined manually in MEGA5 (Tamura et al., 2011). Final alignments comprised 206 and 460 amino acid positions for soxB and rdsrAB, respectively. Phylogenetic trees were constructed with the maximum likelihood method in MEGA5. The sequence data have been submitted to the GenBank database under accession No. KF910786-KF910914 (soxB) and KF910915-KF910961 (rdsrAB).

\section{QUANTITATIVE PCR (qPCR)}

The AlleleID 7.75 software (PREMIER Biosoft) was used on alignments of $s o x B$ and $r d s r A B$ sequences to design a suite of primers targeting divergent phylotypes (Table Supp1). Primers were checked against the nr/nt database using Primer-BLAST on NCBI server (Ye et al., 2012). For each target phylotype, DNA standards were prepared by linearizing plasmids from one representative clone. qPCR reactions were performed on a Mx3005P thermocycler (Stratagene) using the Maxima SYBR Green qPCR Master Mix containing 0.01 $\mu \mathrm{M}$ ROX (Thermo Scientific). For each primer set, qPCR conditions were optimized on serial dilution of the respective standard clone $\left(10-10^{5}\right.$ copies), to ensure satisfying specificity and efficiency above $80 \%$. Reactions were denatured $10 \mathrm{~min}$ at $95^{\circ} \mathrm{C}$, followed by 40 cycles of $15 \mathrm{~s}$ at $95^{\circ} \mathrm{C}$, $30 \mathrm{~s}$ at the specific annealing temperature and $30 \mathrm{~s}$ at $72^{\circ} \mathrm{C}$. Dissociation curves were obtained by heating up the reactions from 65 to $95^{\circ} \mathrm{C}$. PCR efficiency was determined using the standard curve by the formula $E=100^{*}\left(10^{(-1 / \text { slope })}-1\right)$. To check the specificity of each primer set, $\mathrm{qPCR}$ reactions were run using either $1 \mathrm{ng}$ of environmental DNA, a mixture of $10^{4}$ copies of all standard clones or the same mixture without the target standard clone as template. No amplification was detected in the latter case. For the former two cases, a single band of the expected size was observed on $2 \%(\mathrm{wt} / \mathrm{vol})$ agarose gel. Optimized primer concentrations and cycling conditions are given in Table Supp2. Validated qPCR conditions were used on environmental samples, using $1 \mathrm{ng}$ of DNA or $3 \mathrm{ng}$ cDNA (eq.RNA) as template. For each phylotype, reactions were technically duplicated and fresh standard curves were run on the same plate as environmental samples, to determine assay performances (Table Supp2). A single lot of cDNAs was used to minimize the variability due to reversetranscription. To ensure no contribution of the background signal 
Table 1 | Number of reads, OTUs, diversity indices and relative abundance ranges of selected bacterial taxa with known sulfur-oxidizing capabilities.

\begin{tabular}{|c|c|c|c|c|c|c|}
\hline & Number of reads & Number of OTUs & Chao1 & Shannon & \multicolumn{2}{|c|}{ Relative abundance (\%) } \\
\hline Rarefied dataset & $6,574,136$ & 46280 & 48181 & 7.94 & - & - \\
\hline Chlorobi & 175,727 & 510 & 525 & 3.59 & $1.90-4.09$ & $1.36-3.02$ \\
\hline Alphaproteobacteria & 334,184 & 2710 & 2842 & 5.71 & $3.63-8.14$ & $2.06-6.84$ \\
\hline Rhizobiales & 74,355 & 627 & 675 & 4.59 & $0.80-1.83$ & $0.51-1.27$ \\
\hline Rhodobacterales & 111,219 & 671 & 691 & 4.42 & $1.17-2.32$ & $0.65-2.27$ \\
\hline Rhodospirillales & 69,150 & 567 & 587 & 4.03 & $0.60-1.85$ & $0.45-1.53$ \\
\hline Epsilonproteobacteria & 24,991 & 264 & 278 & 4.07 & $0.17-0.77$ & $0.25-0.48$ \\
\hline Campylobacterales & 24,988 & 263 & 277 & 4.06 & $0.16-0.77$ & $0.25-0.48$ \\
\hline Gammaproteobacteria & $1,356,406$ & 5611 & 5859 & 5.18 & $16.11-25.49$ & $15.67-29.04$ \\
\hline Chromatiales & 576,136 & 1633 & 1681 & 3.98 & $6.35-10.44$ & $5.54-14.79$ \\
\hline Thiotrichales & 174,105 & 612 & 637 & 3.29 & $1.79-4.75$ & $1.67-3.28$ \\
\hline Thiohalorhabdus-related & 101,270 & 111 & 117 & 1.20 & $1.00-2.55$ & $1.29-3.92$ \\
\hline
\end{tabular}

to gene quantification, $\mathrm{C}_{\mathrm{T}}$ cut-off thresholds were set 3.3 cycles lower than that for the no-template control, if detected (Smith et al., 2006). Correlation analysis, ANOVA and post-hoc Tukey tests were performed on $\log _{10}(\mathrm{x}+1)$-transformed values in $\mathrm{R}$ v3.0.1 (http://www.R-project.org/).

\section{RESULTS}

\section{TAXONOMIC COMPOSITION}

To identify the major S-oxidizers in salt marshes, we used both phylogenetic analyses of 16S rRNA and genes involved in $\mathrm{S}$-oxidation (soxB and $r d s r \mathrm{AB}$ ).

Over 14 million reads were retrieved from bacterial $16 \mathrm{~S}$ rDNA and rRNA gene amplicon libraries prepared from 23 samples, including all samples from October and 5 selected samples distributed along the depth profile of the July core (Table Supp3). A total of 48,575 OTUs were obtained at the $3 \%$ clustering level. We focused on orders in the phyla Chlorobi and Proteobacteria that are currently known to contain S-oxidizers (Table 1). The most prevalent were Chromatiales and Thiotrichales within the Gammaproteobacteria, and Rhodobacterales within the Alphaproteobacteria. Twenty-nine of the 100 most abundant OTUs belonged to one of these orders (Table 2). Though not the focus of our work, we identified Desulfobacteraceae and Desulfobulbaceae as the dominant sulfatereducing bacteria (unpubl. data), similar to previous studies in salt marshes, including at PIE (Klepac-Ceraj et al., 2004; Bahr et al., 2005).

In total 129 soxB sequences were retrieved from different sediment layers in July at Site 2, including 74 sequences with the general primers and 55 sequences with the Epsilonproteobacteriaspecific primers (Figure 1). At 90\% amino acid identity, 24 distinct OTUs were identified ( 9 were singletons). Rarefaction analysis suggested the sox $\mathrm{B}$ diversity was not completely captured when pooling sequences from both libraries (Figure Supp1).

Phylogenetic reconstruction affiliated the majority of sox $\mathrm{B}$ sequences with Gammaproteobacteria (71 sequences, 14 OTUs). Fifty-five sequences (8 OTUs) were related to Epsilonproteobacteria and only 2 sequences (1 OTU) clustered with Alphaproteobacteria. One soxB singleton was distantly related to Chlorobi, and none of the retrieved sequences clustered with known Betaproteobacteria S-oxidizers. Although Thiohalorhabdus-related sequences were found relatively abundant in the 16S rRNA libraries (Table 1), they were not detected in the soxB library (Figure 1). Using the same primers as we did, Tourova et al. (2013) successfully amplified the soxB gene from the extreme halophile Thiohalorhabdus denitrificans, an unclassified gammaproteobacterial S-oxidizer with no significant relationship to any other genera in this class (Sorokin et al., 2008). Therefore, Thiohalorhabdus-related bacteria detected in the $16 \mathrm{~S}$ rRNA libraries might contain either a divergent soxB or no $s o x \mathrm{~B}$ at all and may not be involved in sulfur oxidation.

$r d s r \mathrm{AB}$ sequences appeared to be less diverse than $s o x \mathrm{~B}$. The clone library comprised 48 sequences representing 13 OTUs (Figure 2), almost fully covering the diversity as suggested by rarefaction analysis (Figure Supp1). All except one sequence clustered with Gammaproteobacteria, mirroring the known distribution of the rDSR pathway, which is mostly present in this class. 
Table 2 | Potential S-oxidizer-affiliated OTUs within the 100 most abundant OTUs of the entire dataset.

\begin{tabular}{|c|c|c|c|c|c|}
\hline \multirow[t]{2}{*}{ Rank } & \multirow[t]{2}{*}{ OTU \# } & \multirow[t]{2}{*}{ Reads number } & \multirow[t]{2}{*}{ Greengenes taxonomy } & \multicolumn{2}{|r|}{ GAST hit } \\
\hline & & & & Genbank ID & Environment \\
\hline 3 & 47537 & 75793 & Chromatiales; Chromatiaceae & AM882561 & Coastal sediment from oil polluted water \\
\hline 7 & 26 & 45073 & Thiohalorhabdus-related & AM259913 & Sponge mesohyl, Adriatic Sea \\
\hline 8 & 38 & 43425 & Thiohalorhabdus-related & AB694476 & Deep-sea sediment at a depth 7111 m \\
\hline 10 & 18 & 42564 & Thiotrichales; Thiotrichaceae & AM882526 & Coastal sediment from oil polluted water \\
\hline 15 & 46316 & 32517 & Chromatiales; Ectothiorhodospiraceae & JX240444 & Coastal soil of Gulf of Khambhat \\
\hline 16 & 46 & 32367 & Chromatiales & JN825489 & $\begin{array}{l}\text { Microbialites from Alchichica alkaline lake } \\
\text { maintained in aquarium }\end{array}$ \\
\hline 19 & 29 & 30098 & Chromatiales; Chromatiaceae & JF344607 & Hydrocarbon polluted marine sediments \\
\hline 22 & 14 & 28188 & Chromatiales & AF170422 & Shallow water hydrothermal vent \\
\hline 26 & 45 & 24393 & Chromatiales & HQ190997 & $\begin{array}{l}\text { Janssand intertidal sediment; German } \\
\text { Wadden Sea }\end{array}$ \\
\hline 27 & 28 & 23825 & Chromatiales & FN553596 & Logatchev hydrothermal vent \\
\hline 29 & 41591 & 19911 & Chromatiales & U77479 & $\begin{array}{l}\text { Bacterial endosymbiont from } \\
\text { Lamellibrachia sp.,Gulf of Mexico seep }\end{array}$ \\
\hline 32 & 15 & 18751 & Chromatiales & FJ497626 & Vailulu'u seamount \\
\hline 37 & 23 & 17739 & Chromatiales; Chromatiaceae; Marichromatium & FN995224 & Seashore sediment \\
\hline 38 & 64 & 17322 & Chromatiales & DQ351776 & Marine sediments \\
\hline 41 & 39 & 16299 & Thiotrichales; Thiotrichaceae & JF344477 & Hydrocarbon polluted marine sediments \\
\hline 52 & 37 & 13622 & Chromatiales; Ectothiorhodospiraceae & GQ259300 & Surface sediment from Arctic fjord \\
\hline 57 & 42 & 12407 & Chromatiales & JF344456 & Hydrocarbon polluted marine sediments \\
\hline 66 & 76 & 11515 & Rhodobacterales; Rhodobacteraceae & DQ015815 & Lake Bonney water. Antarctica \\
\hline 70 & 52 & 11125 & Thiotrichales; Piscirickettsiaceae & JQ580025 & Sediments from Figueiras beach \\
\hline 72 & 53 & 10863 & Thiotrichales; Piscirickettsiaceae & AB694467 & Deep-sea sediment at a depth 7111 m \\
\hline 74 & 102 & 10805 & Chromatiales; Chromatiaceae & AM882562 & Coastal sediment from oil polluted water \\
\hline 76 & 85 & 10555 & Chromatiales & HQ191056 & $\begin{array}{l}\text { Janssand intertidal sediment; German } \\
\text { Wadden Sea }\end{array}$ \\
\hline 78 & 78 & 10316 & Chromatiales & EF999348 & $\begin{array}{l}\text { Pearl River estuary sediments at } 6 \mathrm{~cm} \\
\text { depth }\end{array}$ \\
\hline 81 & 87 & 10085 & Chromatiales & EU488541 & $\begin{array}{l}\text { Gill symbiont from lucinid clam in sea } \\
\text { grass beds }\end{array}$ \\
\hline 87 & 68 & 9431 & Rhodospirillales; Rhodospirillaceae & JX240999 & Coastal soil of Gulf of Khambhat \\
\hline 93 & 79 & 8794 & Rhodospirillales; Rhodospirillaceae & EU834757 & Lab scale EBPR-activated sludge \\
\hline 95 & 73 & 8393 & Thiotrichales; Piscirickettsiaceae & JN166335 & Hawaii Ocean Time series, depth $=350 \mathrm{~m}$ \\
\hline 98 & 104 & 8154 & Rhodobacterales; Rhodobacteraceae & JN435530 & Guerrero negro hypersaline mat \\
\hline 100 & 28653 & 8142 & Chromatiales; Chromatiaceae & FJ437964 & $\begin{array}{l}\text { Green lake surface sediments at } 16.5 \mathrm{~m} \\
\text { water depth }\end{array}$ \\
\hline
\end{tabular}

\section{DEPTH PROFILE OF S-OXIDIZER GENES AND TRANSCRIPTS}

Using the "mix" samples collected in July at Site 2, we estimated the variations in abundance (i.e., DNA level) and transcriptional activity (i.e., RNA level) of S-oxidizers from surface to $20 \mathrm{~cm}$ using two methods: $16 \mathrm{~S}$ rRNA amplicon tag sequencing, and newly designed $\mathrm{qPCR}$ assays of selected $\operatorname{sox} \mathrm{B}$ and $r d s r \mathrm{AB}$ phylotypes.

Based on bacterial $16 \mathrm{~S}$ reads at the DNA level, the relative abundance of the orders containing potential S-oxidizers was stable along the depth profile (Figure 3), with Chromatiales and Thiotrichales the dominant groups. At the RNA level, the contribution of Chromatiales increased with depth, from $7 \%$ at the sediment surface to $15 \%$ between 16 and $18 \mathrm{~cm}$ (Spearman's rank correlation coefficient $\rho=1.00, P=0.017$ ), whereas the contribution of the three alphaproteobacterial orders Rhizobiales, Rhodobacterales and Rhodospirillales decreased with depth ( $\rho=-1.00, P<0.02$ for all 3 orders).

qPCR assays showed that the distribution of functional gene copies with sediment depth does not match the distribution of transcripts (Figure 4). For sox $\mathrm{B}$, the total copy numbers at the DNA level was positively correlated with depth $(\rho=0.65, P=$ 0.049, Figure 4A). Together, the Thiotrichales-related phylotypes soxB-2 and $s o x \mathrm{~B}-3$ were the most abundant at all depths except at the surface where the Congregibacter-related soxB-1 contributed $60 \%$ of the total gene copies measured. Below $14 \mathrm{~cm}$, the abundance of Epsilonproteobacteria-related soxB-6 increased. Positive correlations between copy numbers of individual phylotypes and sediment depth were detected for $\operatorname{sox\mathrm {B}-2}(\rho=0.70, P=0.031)$, 


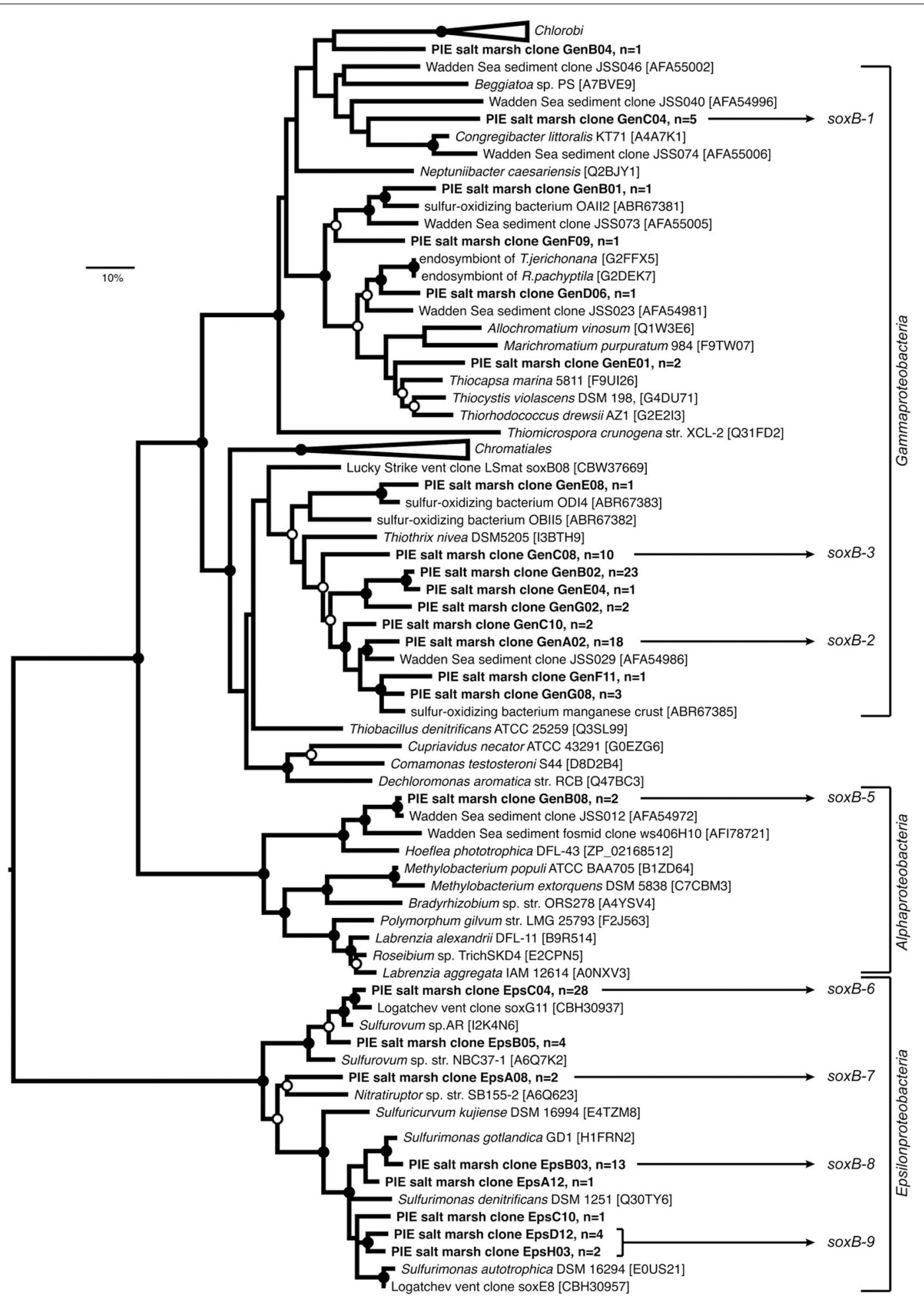

FIGURE 1 | Maximum-likelihood (ML) phylogenetic reconstruction of SoxB proteins deduced from sequences cloned from Plum Island Estuary salt marsh sediments (in boldface), including publicly available SoxB sequences from reference strains and uncultured bacteria (accession numbers are given). The $W A G+G$ substitution model was used (100 re-samplings, $G=1.21, I=0.10$ ) based on testing different models in MEGA5. OTUs defined at $90 \%$ identity threshold are represented by one selected clone; " $n$ " equals number of sequences per
OTU. Sequences annoted as "Gen" and "Eps" were retrieved from the clone libraries prepared using the general and Epsilonproteobacteriaspecific soxB primer pairs, respectively. ML bootstrap support (100 resamplings) greater than $50 \%$ (open circles) and $70 \%$ (black circles) are displayed. The tree was rooted on the Epsilonproteobacteria branch. The bar indicates $10 \%$ sequence divergence. OTUs used to design soxB primer sets targeting selected phylotypes for qPCR are shown (soxB 1-9, Table Supp1). 


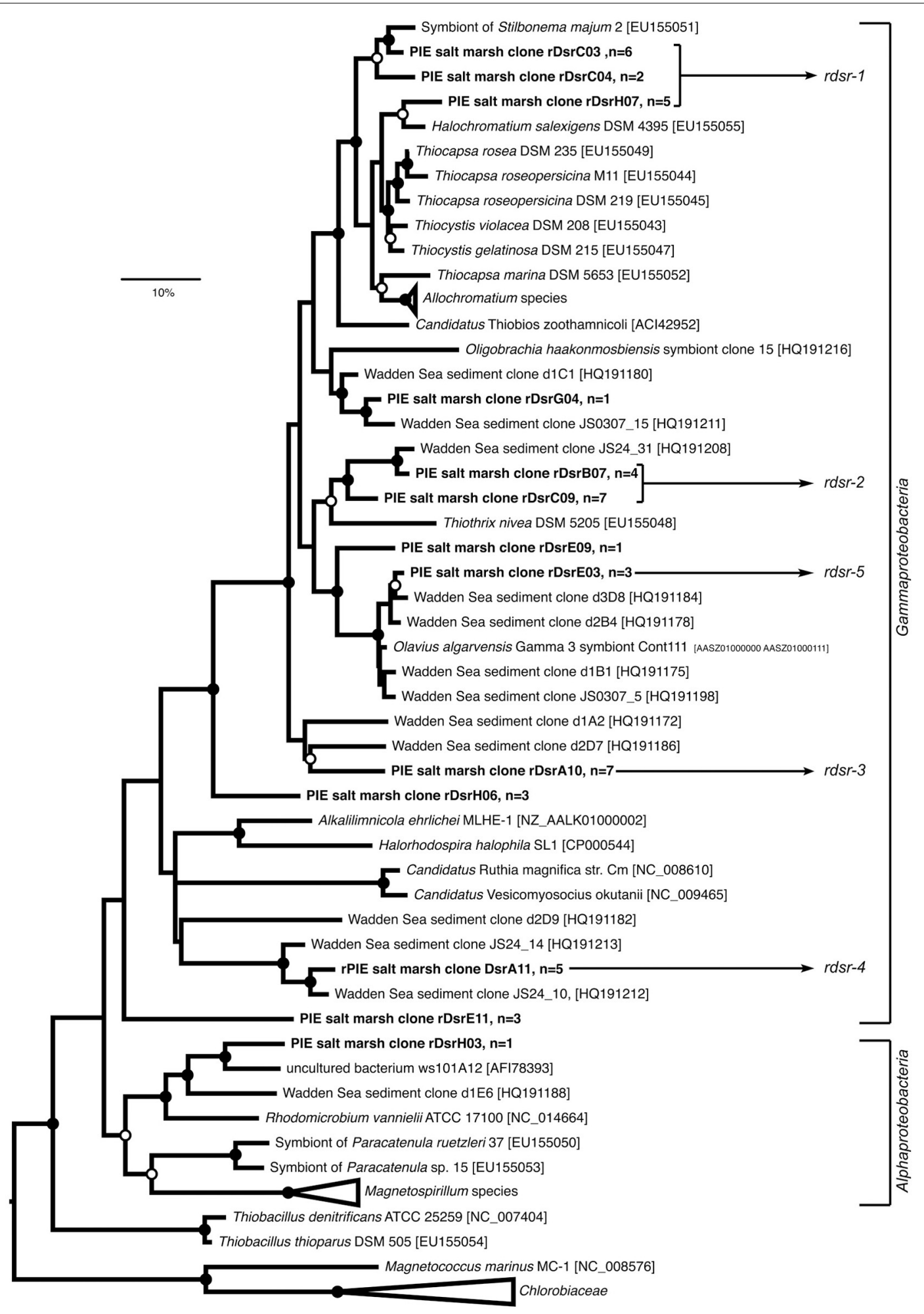

FIGURE 2 | Maximum-likelihood (ML) phylogenetic reconstruction of rDsrAB proteins deduced from sequences cloned from Plum Island Estuary salt marsh sediments (in boldface), including publicly available rDsrAB sequences from reference strains and uncultured bacteria (accession numbers are given). The $W A G+G$ substitution

model was used (100 re-samplings, $G=1.17, I=0.19$ ) based on testing different models in MEGA5. OTUs defined at $90 \%$ identity threshold are represented by one selected clone; " $n$ " equals number of sequences per OTU. ML bootstrap support (100 resamplings) greater than 50\% (open circles) and $70 \%$ (black circles) are displayed. Sequences from

Magnetococcus marinus and Chlorobiaceae were used as outgroups. The bar indicates $10 \%$ sequence divergence. OTUs used to design rdsrAB primer sets targeting selected phylotypes for qPCR are shown (rdsr 1-5, Table Supp1). 


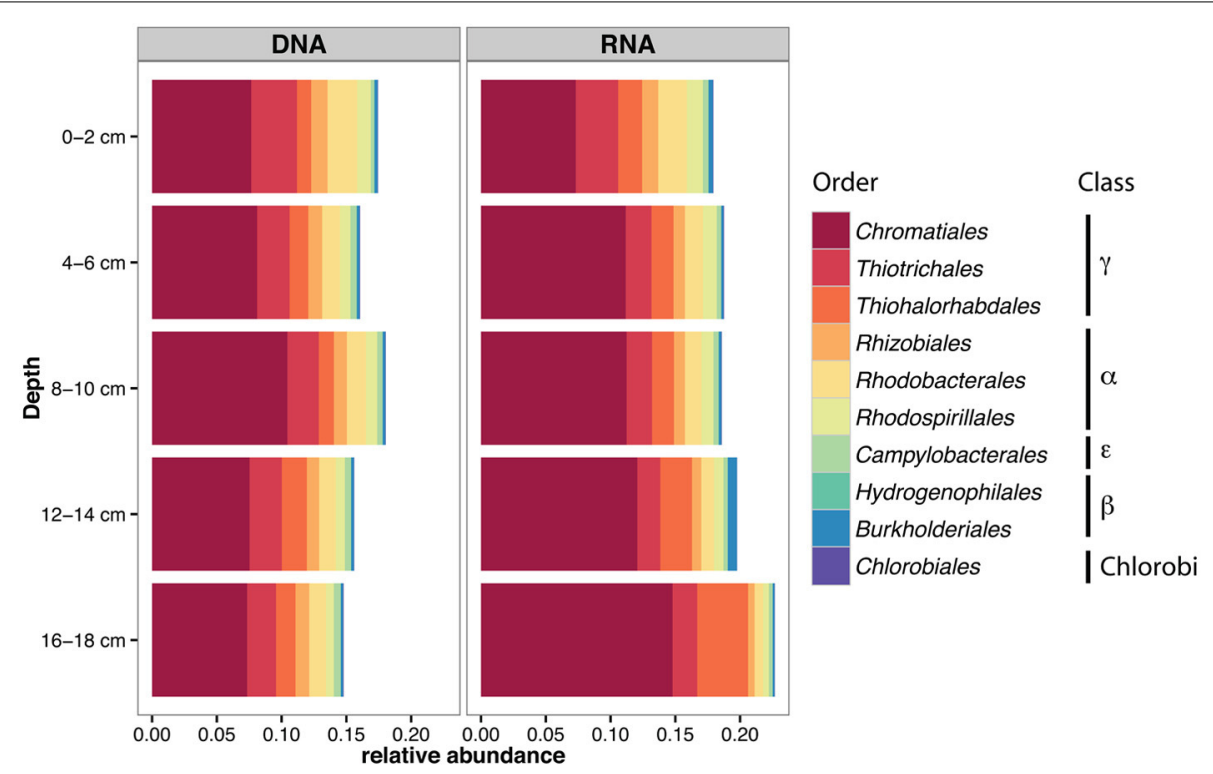

FIGURE 3 | Relative abundance of bacterial orders comprising S-oxidizers in 16S rRNA amplicon libraries from different depths in July at Site 2, in the DNA and RNA fractions.

soxB-6 $(\rho=0.96, P<0.001)$ and $\operatorname{soxB}-8(\rho=0.73, P=0.021)$. At the RNA level (Figure 4C), there was a strong decline with depth in total soxB transcript numbers $(\rho=-0.94, P<0.001)$. Significant negative correlations were found for the phylotypes so $\times \mathrm{B}-1$ to $s o \times \mathrm{B}-5$, but not for the Epsilonproteobacteria-related soxB-6 to soxB-9. Similar to what was observed at the DNA level, transcripts of the Thiothrix-related sox $\mathrm{B}-2$ and $s o x \mathrm{~B}-3$ were the most detected soxB phylotypes.

For $r d s r \mathrm{AB}$ phylotypes, the total copy number was 1-3 orders of magnitude higher than that of $s o x \mathrm{~B}$ in all samples both at DNA and RNA levels (Figures 4B,D) and decreased with depth (DNA: $\rho=-0.72, P=0.024$; RNA: $\rho=-0.93, P<0.001)$. Significant negative correlations $(-0.95<\rho<-0.71, P<0.021)$ were found between sample depth and transcript numbers for all $r d s r \mathrm{AB}$ phylotypes. The Chromatiales-related phylotype $r d s r 1$ was by far the most abundant and expressed.

\section{EFFECT OF SITE AND SMALL-SCALE COMPARTMENTS ON S-OXIDIZER COMMUNITIES}

Samples collected in October at $5 \mathrm{~cm}$ depth were used to investigate the variations in S-oxidizer community composition, abundance and transcriptional activity at two sites and in three different compartments (mix, rhizosphere and roots). PCoA of potential S-oxidizers 16S rRNA OTUs (Figure 5) showed that the composition of the community differed strongly according to sampling site, both at the DNA level [PERMANOVA, $\left.F_{(1,16)}=13.27, \quad P<0.001, R^{2}=0.45\right]$ and RNA level [PERMANOVA, $\quad F_{(1,16)}=11.38, \quad P<0.001, \quad R^{2}=0.42$ ]. This was mainly due to enrichment in Alphaproteobacteria at Site 1 and in Chromatiaceae, Beta- and Epsilon proteobacteria at Site 2 , as revealed by the LEfSe analysis (Figure 6). In addition, there was a significant effect of the compartment within Site 1 and Site 2 at the DNA level [PERMANOVA, $F_{(2,15)}=0.95, P=0.008$,
$\left.R^{2}=0.112\right]$, where communities in "roots" samples tended to cluster away from rhizosphere samples (Figure 5, top panel).

In general, total $r d s r \mathrm{AB}$ gene and transcripts numbers (Figure 7B) were 1-3 orders of magnitude higher than those of sox $\mathrm{B}$ (Figure 7A). In all three compartments, Chromatiales and Thiotrichales represented the most abundant and expressed phylotypes for $r d s r \mathrm{AB}(r d s r-1)$ and $s o x \mathrm{~B}(s o x \mathrm{~B}-2$ and 3), respectively (Figure 7). No differences between the mix and rhizosphere samples were found for the copy and transcript numbers of any soxB or $r d s r \mathrm{AB}$ phylotype (Figures Supp2-Supp5). In contrast, significant differences were observed between roots samples and at least one other compartment for Gamma- and Epsilonproteobacteria phylotypes.

Gene copy abundances for the Gammaproteobacteria-related sox $\mathrm{B}$ phylotypes (soxB-1, -2, and -3) were lower in roots samples than in mix samples at Site 2 (Figure Supp2). At Site 1, the same trend was apparent but the pattern was significant only for soxB-3. No significant differences were found at the transcript level (Figure Supp3). For the five Gammaproteobacteria-related $r d s r A B$ phylotypes, no significant differences in gene copy abundance were found in roots vs. mix samples (Figure Supp4), but three of the five phylotypes ( $r d s r-2,-3$, and -4$)$ showed decreased transcript abundance in roots samples compared to mix samples at Site 2 (Figure Supp5).

Gene copy and transcript numbers of Epsilonproteobacteria soxB-phylotypes (soxB-6, -7, -8- and -9) were much higher at Site 2 , in line with the 16S rRNA data. At this site, their contribution tended to increase on Spartina roots samples compared to the mix samples (Figure Supp2), and the pattern for soxB-7, and soxB-9 was significant. Transcripts for all Epsilonproteobacteriarelated sox $\mathrm{B}$ phylotypes tended to be present in higher numbers in roots samples (compared to mix and rhizosphere) at Site 2 (Figure Supp3), though small sample size $(n=3)$ and 



FIGURE 4 | Variations in gene $(A, B)$ and transcript $(C, D)$ abundance for soxB $(A, C)$ and rdsrAB phylotypes $(B, D)$ as a function of depth in July at Site 2. Copy numbers were calculated using standard curve and efficiency as reported in Table Supp2.

high variability precluded statistical significance (e.g., for soxB-9, $P=0.09$ ).

\section{DISCUSSION}

CHROMATIALES AND THIOTRICHALES ARE DOMINANT S-OXIDIZERS IN SALT MARSH SEDIMENTS

$16 \mathrm{~S}$ rRNA tag sequencing, phylogenetic analyses of soxB and $r d s r \mathrm{AB}$ genes, as well as quantification of their copy and transcript numbers congruently showed that Gammaproteobacteria, especially members of the orders Chromatiales and Thiotrichales, are the dominant S-oxidizers in salt marsh sediments populated with S. alterniflora. S-oxidizing members of the Alpha- and Epsilonproteobacteria classes were also detected, although in lower numbers. The dominant taxa were only distantly related to cultivated strains of S-oxidizers and mainly grouped with uncultured environmental bacteria, underlining the lack of knowledge on sulfur-oxidation in salt marshes.

Dominance of gammaproteobacterial S-oxidizers was also found in unvegetated intertidal sediments of the German Wadden Sea, mostly belonging to uncultured clades or related to Thiothrix nivea (Lenk et al., 2011). In addition, we identified organisms related to Congregibacter litoralis belonging to the NOR5/OM60 clade, also detected in Wadden Sea sediments (Lenk et al., 2011, 2012). Interestingly, we show that the phylotype belonging to this clade (soxB-1) is transcribed in surface salt marsh sediments, even though evidence for thiotrophy is currently lacking for this clade 


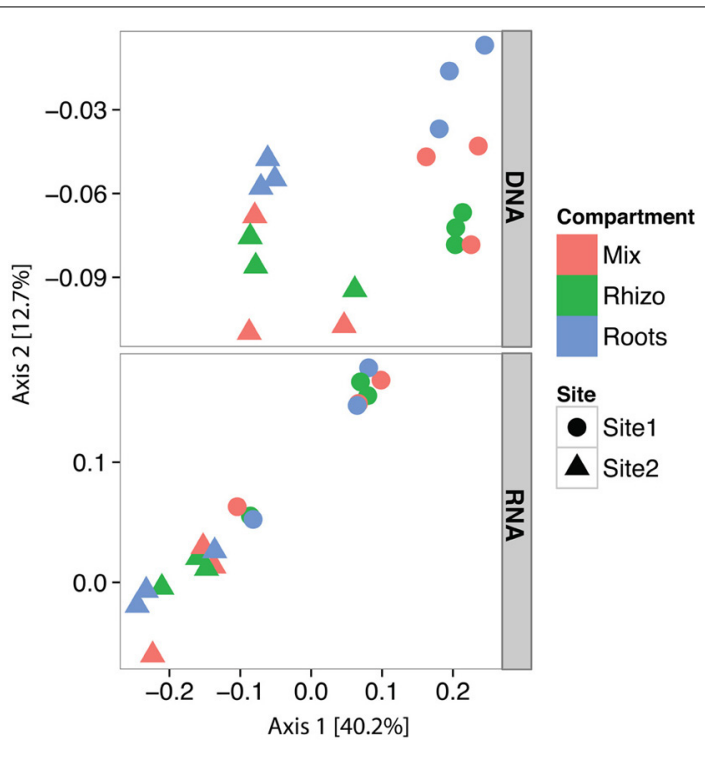

FIGURE 5 | Principal Coordinates Analysis (PCoA) plots of the potential S-oxidizer community composition in relation to nucleic acid, sampling site and small-scale compartment sampled. PCOA ordination was performed on 16S rRNA amplicon sequence data for DNA and cDNA together, but displayed in distinct panels for clarity. All OTUs affiliated to orders listed in Table 1 were used.

(Fuchs et al., 2007; Lenk et al., 2012). S-oxidizers belonging to Chromatiales were identified as an important group in our study, while they were absent in the Wadden Sea sediments (Lenk et al., 2011). Most of the epsilonproteobacterial S-oxidizers we identified in the salt marsh sediments were related to Sulfurovum and Sulfurimonas, similar to those found in other reduced marine environments, including tidal mud flats (Timmer-Ten Hoor, 1975), pelagic redoxclines (e.g., Grote et al., 2008; Bruckner et al., 2012), cold seeps (e.g., Niemann et al., 2013) and hydrothermal vents (e.g., Hügler et al., 2010; Akerman et al., 2013). What might make this particular group of S-oxidizers successful in these different habitats is an outstanding question.

Our study is the first to quantify $r d s r \mathrm{AB}$ and $s o x \mathrm{~B}$ genes simultaneously in the environment. The higher copy numbers of $r d s r \mathrm{AB}$ compared to $\operatorname{sox} \mathrm{B}$ was unexpected, as bacteria featuring the reverse-DSR pathway typically possess both genes and use the SOX system to oxidize thiosulfate (Kappler and Dahl, 2001). This discrepancy could be explained by the fact that we were unable to design specific primers for some potentially abundant sox $\mathrm{B}$ phylotypes (e.g., targeting GenE01 or GenB02, Figure 1). However, as $r d s r \mathrm{AB}$ genes are usually present in only one copy per genome (Loy et al., 2009), this could also point to some S-oxidizers using the reverse-DSR pathway either possessing a divergent SOX system or lacking it, in which case they might be unable to utilize thiosulfate (Petri et al., 2001; Meyer et al., 2007).

\section{DISTRIBUTION OF SOXB AND rdsrAB GENE COPIES DOES NOT MATCH THE DISTRIBUTION OF TRANSCRIPTS WITH DEPTH}

Our data suggest that the transcriptional activity of the Soxidizers occurs mainly in the upper $5 \mathrm{~cm}$, largely following the expected distribution of root biomass (Davey et al., 2011). The decrease in transcription in deeper sediments may be due to a depletion of potential electron acceptors such as oxygen or nitrate, which are both influenced by the roots, either directly in the case of oxygen (via provision of $\mathrm{O}_{2}$ through aerenchyma or use of $\mathrm{O}_{2}$ for respiration), or indirectly via rhizosphere nitrification in the case of nitrate. In addition, inhibition by high sulfide concentration could occur (Ruby and Jannasch, 1982; Wirsen et al., 2002). Interestingly, transcripts of the Thiotrichales-affiliated phylotypes soxB-2 and soxB-3 were still detected below $10 \mathrm{~cm}$, but the $r d s r-2$ phylotype (also affiliated to Thiotrichales) was barely expressed (Figures 4C,D). For these organisms, this transcriptional uncoupling between sox $\mathrm{B}$ and $r d s r \mathrm{AB}$ could be due to a lack of terminal electron acceptors, which would prevent the full oxidation of reduced sulfur compounds all the way to sulfate. This might lead to the accumulation of elemental sulfur as an intermediate due to a repression of $r d s r \mathrm{AB}$, which is involved in the remobilisation of sulfur globules as the first step to complete the oxidation to sulfate.

Overall, the abundance of $s o x \mathrm{~B}$ genes from Epsilonproteobacteria (soxB-6 to soxB-9) increased with depth (Figure 4A), but transcript numbers did not. However, because soxB-1, soxB-2, and soxB-3 transcript numbers plummeted with depth, the relative abundance of $s o x \mathrm{~B}-6$ to soxB-9 transcripts increased, accounting for about $30 \%$ of the detected sox $\mathrm{B}$ transcripts below $12 \mathrm{~cm}$. So far all characterized sulfur-oxidizing Epsilonproteobacteria lack the reverse-DSR pathway, therefore relying on the SOX pathway for S-oxidation. As discussed above, soxB-2 and soxB-3 transcripts from Thiotrichales detected below $10 \mathrm{~cm}$ may reflect partial S-oxidation to elemental sulfur. Although found in low absolute abundance, Epsilonproteobacteria may thus account for a significant portion of S-oxidation in deeper salt marsh sediments, perhaps enabled by their association with Spartina roots and their adaptation to microaerobic conditions (see below).

\section{MICROBIAL COMMUNITY MEMBERSHIP AND TRANSCRIPTIONAL ACTIVITY VARY BETWEEN SITES 1 AND 2 THOUGH BOTH ARE VEGETATED WITH S. ALTERNIFLORA}

We observed pronounced differences in S-oxidizer communities between the two sampling locations, even though both were vegetated with the same plant. The transcription of S-oxidizing genes was generally lower at Site 1. Furthermore, Epsilonproteobacteria and Chromatiales-related phylotypes were present in higher abundance at Site 2 (Figures 6, 7, Supp2, Supp3). In contrast, Alphaproteobacteria-related S-oxidizers were found in higher abundance at Site 1 based on the 16S rRNA libraries (Figure 6). Some of these patterns may relate to different salinity and flooding conditions. Site 2 , which is closer to the mouth of the estuary and away from the creekbank, has a higher salinity and less frequent tidal flushing. Samples from Site 1 were collected directly at the creekbank, which based on previous work is characterized by lower sulfate reduction rates as compared to interior marsh sites, likely due to more extensive porewater drainage and air entry favoring aerobic decomposition (Howarth and Giblin, 1983; King, 1988). In addition, more frequent and longer tidal flushing may prevent the accumulation of sulfide at Site 1. Indeed, 


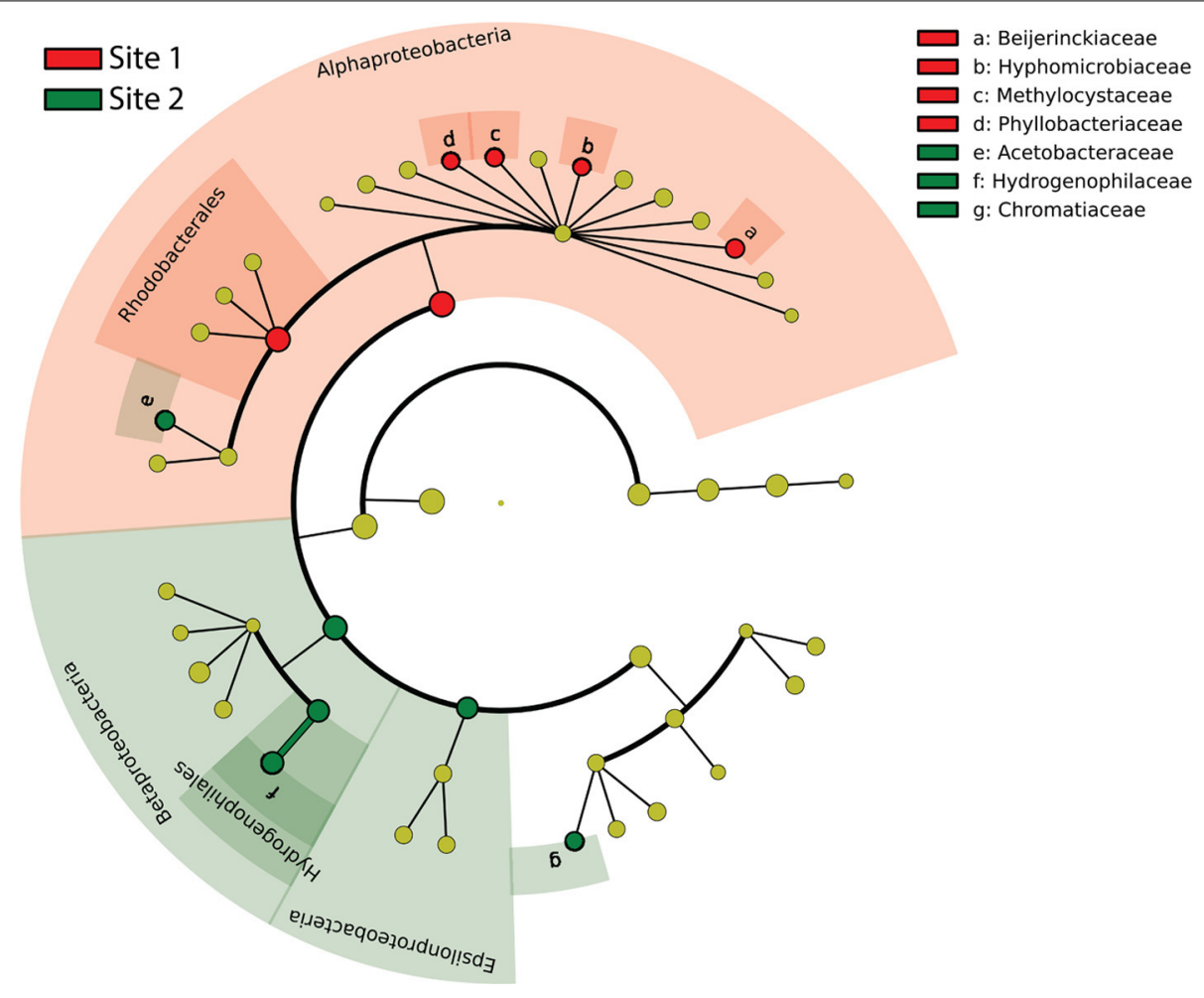

FIGURE 6 | Cladogram indicating the taxonomic distribution of potential S-oxidizer lineages statistically different between sampling sites, based on $16 \mathrm{~S}$ rRNA amplicon sequence data. Lineages with LDA 2.0 or higher determined by LEfSe are displayed. Red circles and shading indicate lineages enriched at Site 1; green circles and shading indicate lineages enriched at Site 2. Yellow circles denote non-significantly different lineages. subsequent measurements obtained in July 2013 for porewater at $5 \mathrm{~cm}$ depth showed higher concentrations of sulfide at Site 2 $(0.7-1.6 \mathrm{mM})$ than at Site $1(0-0.01 \mathrm{mM}$, unpublished). Thus, conditions at Site 2 are likely to favor Epsilonproteobacteria, which have predominantly been identified from sulfidic marine environments, and are generally known to tolerate higher sulfide concentrations (Wirsen et al., 2002; Campbell et al., 2006).

\section{EVIDENCE FOR SMALL-SCALE NICHE STRUCTURE IN THE RHIZOSPHERE}

At the DNA level, our results showed a significant effect of the compartment on the composition of S-oxidizer communities based on 16S rRNA tags, with roots samples differing from rhizosphere (Figure 5). Interestingly, the same effect was not observed at the RNA level, suggesting that though active community composition varies among sites and in roots relative to surrounding sediments, a common pool of S-oxidizers is active across compartments. Marker genes for S-oxidation were detected in the DNA and RNA fractions of mix, rhizosphere and roots samples. This suggests that $\mathrm{S}$-oxidizers grow and are active in all compartments, although the expression of fully functional S-oxidation pathways would need to be confirmed at the protein level. We further observed distinct patterns in gene and transcript numbers of sox $\mathrm{B}$ and $r d s r \mathrm{AB}$ phylotypes on the roots. Therefore, the S. alterniflora root environment actually influences S-oxidizers from a common pool of species by fine-tuning their abundance and transcriptional activity. In particular, the global expression of $\operatorname{sox} \mathrm{B}$ was higher at both sites on the roots compared to mix and rhizosphere samples (Figure 7), suggesting that the root surface environment might favor the activity of some S-oxidizers in vegetated sediments. They might benefit from the localized production of sulfide by root-associated sulfate-reducers (Hines et al., 1999) and the release of oxygen from the roots, enabling their activity in deeper sediments. In addition, denitrifying Soxidizers would also be able to use nitrate formed around the roots by nitrification (Hamersley and Howes, 2005).

Most of the $r d s r \mathrm{AB}$ and $s o x \mathrm{~B}$ transcripts detected on the roots belonged to Gammaproteobacteria, largely dominated by $r d s r-1$ and soxB-2, respectively. However, we found an interesting pattern for Epsilonproteobacteria at Site 2, where this class was enriched. Although Epsilonproteobacteria were only a minor fraction of the sox $\mathrm{B}$ phylotypes detected in mix and rhizosphere samples, they accounted on average for 56 and $26 \%$ of the soxB copies and transcripts detected on roots, respectively. This suggests that the root system of $S$. alterniflora might constitute a preferential niche for the establishment of sulfur-oxidizing Epsilonproteobacteria, compared to the surrounding sediment. This finding was not expected considering that cultivated S-oxidizing Epsilonproteobacteria are known to be microaerophiles and to use oxygen-sensitive enzymes for carbon fixation (Hügler and Sievert, 2011). Further work to characterize the conditions in the rhizoplane in more detail and/or isolation and characterization of sulfur-oxidizing Epsilonproteobacteria from root surfaces is required to solve this apparent paradox. 

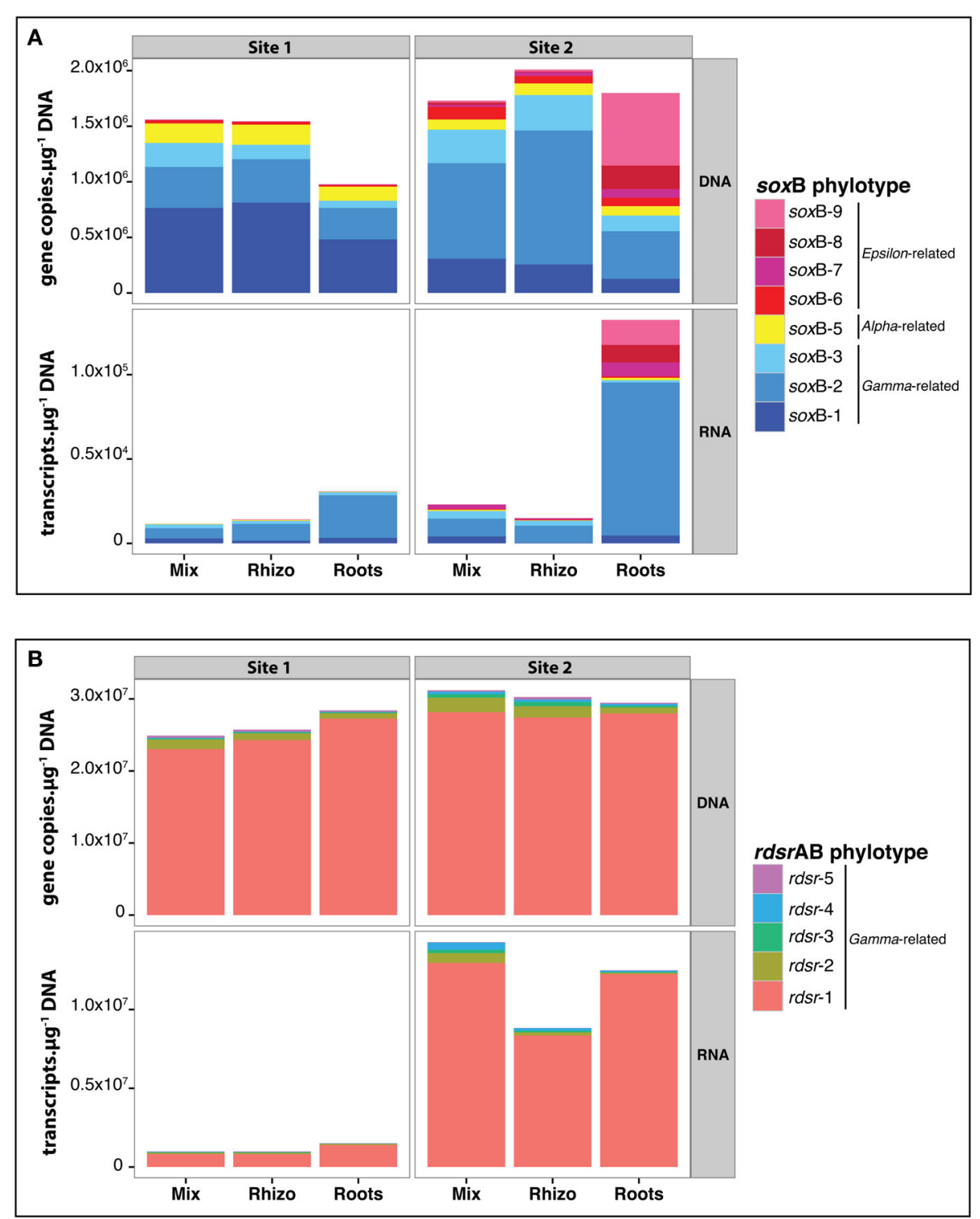

FIGURE 7 | Variations in gene and transcript abundance for soxB (A) and rdsrAB phylotypes (B) for samples at $5 \mathrm{~cm}$ depth from the two sites in October. Values are mean copy numbers $(n=3)$. Copy numbers were calculated using standard curves and efficiencies reported in Table Supp2. Details (including standard errors) for each phylotype are given in Figures Supp2-Supp5.
Previous studies reported the capacity of $S$. alterniflora root tips to oxidize sulfide via both enzymatic and non-enzymatic mechanisms (Lee, 1999). To our knowledge, this is the first identification of specific bacterial groups on S. alterniflora roots that could contribute to S-oxidation. The present study complements the existing knowledge on the sulfur cycle in salt marshes by providing lacking information on its oxidative part, setting the stage for future investigations exploring the effect of environmental conditions and plant-microorganism interactions in more detail. In particular, we showed the expression of genes for two S-oxidation pathways up to the transcript level, which would need to be supplemented with proteomic studies and rate measurements. Furthermore, the evidence for small-scale heterogeneity of S-oxidizers in the rhizosphere underlines the need to develop new biogeochemical techniques enabling non-destructive measurements of chemical concentrations and process rates in situ at the required sub-millimeter level.

\section{ACKNOWLEDGMENTS}

This work was supported by NSF Ecosystems Studies grants DEB1050557 (Stefan M. Sievert) and DEB-1050713 (Zoe G. Cardon, Anne E. Giblin). Logistical support was provided by the PIELTER (NSF grant OCE-1238212). We thank Suzanne Thomas and Jérôme Dabin for assistance in the field, as well as Joseph Vineis and Hilary Morrison for their advice and help on the HiSeq sequencing. 


\section{SUPPLEMENTARY MATERIAL}

The Supplementary Material for this article can be found online at: http://www.frontiersin.org/journal/10.3389/fmicb. 2014.00309/abstract

\section{REFERENCES}

Akerman, N. H., Butterfield, D. A., and Huber, J. A. (2013). Phylogenetic diversity and functional gene patterns of sulfur-oxidizing subseafloor Epsilonproteobacteria in diffuse hydrothermal vent fluids. Front. Microbiol. 4:185. doi: $10.3389 /$ fmicb.2013.00185

Bahr, M., Crump, B. C., Klepac-Ceraj, V., Teske, A., Sogin, M. L., and Hobbie, J. E. (2005). Molecular characterization of sulfate-reducing bacteria in a New England salt marsh. Environ. Microbiol. 7, 1175-1185. doi: 10.1111/j.14622920.2005.00796.x

Bradley, P. M., and Morris, J. T. (1990). Influence of oxygen and sulfide concentration on nitrogen uptake kinetics in Spartina alterniflora. Ecology 71, 282-287. doi: $10.2307 / 1940267$

Bruckner, C. G., Mammitzsch, K., Jost, G., Wendt, J., Labrenz, M., and Jürgens, K. (2012). Chemolithoautotrophic denitrification of epsilonproteobacteria in marine pelagic redox gradients. Environ. Microbiol. 15, 1505-1513. doi: 10.1111/j.1462-2920.2012.02880.x

Brunet, R. C., and Garcia-Gil, L. J. (1996). Sulfide-induced dissimilatory nitrate reduction to ammonia in anaerobic freshwater sediments. FEMS Microbiol. Ecol. 21, 131-138. doi: 10.1111/j.1574-6941.1996.tb00340.x

Burgin, A. J., and Hamilton, S. K. (2007). Have we overemphasized the role of denitrification in aquatic ecosystems? A review of nitrate removal pathways. Front. Ecol. Environ. 5, 89-96. doi: 10.1890/1540-9295(2007)5[89:HWOTRO]2.0.CO;2

Campbell, B. J., Engel, A. S., Porter, M. L., and Takai, K. (2006). The versatile epsilon-proteobacteria: key players in sulphidic habitats. Nat. Rev. Microbiol. 4, 458-468. doi: 10.1038/nrmicro1414

Caporaso, J. G., Kuczynski, J., Stombaugh, J., Bittinger, K., Bushman, F. D., Costello, E. K., et al. (2010). QIIME allows analysis of high-throughput community sequencing data. Nat. Methods 7, 335-336. doi: 10.1038/nmeth.f.303

Davey, E., Wigand, C., Johnson, R., Sundberg, K., Morris, J., and Roman, C. T. (2011). Use of computed tomography imaging for quantifying coarse roots, rhizomes, peat, and particle densities in marsh soils. Ecol. Appl. 21, 2156-2171. doi: 10.1890/10-2037.1

Devereux, R., Hines, M., and Stahl, D. (1996). S Cycling: Characterization of natural communities of sulfate-reducing bacteria by $16 \mathrm{~S}$ rRNA sequence comparisons. Microb. Ecol. 32, 283-292. doi: 10.1007/BF00183063

Edgar, R. C. (2010). Search and clustering orders of magnitude faster than BLAST. Bioinformatics 26, 2460-2461. doi: 10.1093/bioinformatics/btq461

Eren, A. M., Vineis, J. H., Morrison, H. G., and Sogin, M. L. (2013). A filtering method to generate high quality short reads using Illumina paired-end technology. PLoS ONE 8:e66643. doi: 10.1371/journal.pone.0066643

Friedrich, C. G., Rother, D., Bardischewsky, F., Quentmeier, A., and Fischer, J. (2001). Oxidation of reduced inorganic sulfur compounds by bacteria: emergence of a common mechanism? Appl. Environ. Microbiol. 67, 2873-2882. doi: 10.1128/AEM.67.7.2873-2882.2001

Fuchs, B. M., Spring, S., Teeling, H., Quast, C., Wulf, J., Schattenhofer, M., et al. (2007). Characterization of a marine gammaproteobacterium capable of aerobic anoxygenic photosynthesis. Proc. Natl. Acad. Sci. U.S.A. 104, 2891-2896. doi: 10.1073/pnas.0608046104

Ghosh, W., and Dam, B. (2009). Biochemistry and molecular biology of lithotrophic sulfur oxidation by taxonomically and ecologically diverse bacteria and archaea. FEMS Microbiol. Rev. 33, 999-1043. doi: 10.1111/j.15746976.2009.00187.x

Giblin, A. E., and Howarth, R. W. (1984). Porewater evidence for a dynamic sedimentary iron cycle in salt marshes. Limnol. Oceanogr. 29, 47-63. doi: 10.4319/lo.1984.29.1.0047

Giblin, A. E., and Wieder, R. K. (1992). "Sulphur cycling in marine and freshwater wetlands," in Sulphur Cycling on the Continents: Wetlands, Terrestrial Ecosystems, and Associated Water Bodies, eds R. W. Howarth, J. W. B. Steward, and M. V. Ivanov (Chichester: Jon Wiley and Sons), 85-117.

Grote, J., Jost, G., Labrenz, M., Herndl, G. J., and Jürgens, K. (2008). Epsilonproteobacteria represent the major portion of chemoautotrophic bacteria in sulfidic waters of pelagic redoxclines of the Baltic and Black Seas. Appl. Environ. Microbiol. 74, 7546-7551. doi: 10.1128/AEM.01186-08

Hamersley, M. R., and Howes, B. L. (2005). Coupled nitrification-denitrification measured in situ in a Spartina alterniflora marsh with a ${ }^{15} \mathrm{NH}_{4}^{+}$tracer. Mar. Ecol. Prog. Ser. 299, 123-135. doi: 10.3354/meps299123

Hines, M. E., Evans, R. S., Sharak Genthner, B. R., Willis, S. G., Friedman, S., Rooney-Varga, J. N., et al. (1999). Molecular phylogenetic and biogeochemical studies of sulfate-reducing bacteria in the rhizosphere of Spartina alterniflora. Appl. Environ. Microbiol. 65, 2209-2216.

Hines, M. E., Knollmeyer, S. L., and Tugel, J. B. (1989). Sulfate reduction and other sedimentary biogeochemistry in a northern New England salt marsh. Limnol. Oceanogr. 34, 578-590. doi: 10.4319/lo.1989.34.3.0578

Holmer, M., Gribsholt, B., and Kristensen, E. (2002). Effects of sea level rise on growth of Spartina anglica and oxygen dynamics in rhizosphere and salt marsh sediments. Mar. Ecol. Prog. Ser. 225, 197-204. doi: 10.3354/meps225197

Howarth, R. W., and Giblin, A. (1983). Sulfate reduction in the salt marshes at Sapelo Island, Georgia. Limnol. Oceanogr. 28, 70-82. doi: 10.4319/lo.1983.28.1.0070

Howarth, R. W., and Hobbie, J. E. (1982). "The regulation of decomposition and heterotrophic microbial activity in salt marsh soils: a review," in Estuarine Comparisons, ed V. S. Kennedy (New York, NY: Academic Press), 183-207.

Howarth, R. W., and Teal, J. M. (1980). Energy flow in a salt marsh ecosystem: the role of reduced inorganic sulfur compounds. Am. Nat. 116, 862-872. doi: $10.1086 / 283674$

Huang, Y., Niu, B., Gao, Y., Fu, L., and Li, W. (2010). CD-HIT Suite: a web server for clustering and comparing biological sequences. Bioinformatics 26, 680-682. doi: 10.1093/bioinformatics/btq003

Huber, J. A., Mark Welch, D. B., Morrison, H. G., Huse, S. M., Neal, P. R., Butterfield, D. A., et al. (2007). Microbial population structures in the deep marine biosphere. Science 318, 97-100. doi: 10.1126/science.1146689

Hügler, M., Gärtner, A., and Imhoff, J. F. (2010). Functional genes as markers for sulfur cycling and $\mathrm{CO}_{2}$ fixation in microbial communities of hydrothermal vents of the Logatchev field. FEMS Microbiol. Ecol. 73, 526-537. doi: 10.1111/j.1574-6941.2010.00919.x

Hügler, M., and Sievert, S. (2011). Beyond the calvin cycle: autotrophic carbon fixation in the ocean. Ann. Rev. Mar. Sci. 3, 261-289. doi: 10.1146/annurev-marine120709-142712

Huse, S. M., Dethlefsen, L., Huber, J. A., Mark Welch, D., Welch, D. M., Relman, D. A., et al. (2008). Exploring microbial diversity and taxonomy using SSU rRNA hypervariable tag sequencing. PLoS Genet. 4:e1000255. doi: 10.1371/journal.pgen.1000255

Joshi, M. M., and Hollis, J. P. (1977). Interaction of Beggiatoa and rice plant: detoxification of hydrogen sulfide in the rice rhizosphere. Science 195, 179-180. doi: $10.1126 /$ science.195.4274.179

Kappler, U., and Dahl, C. (2001). Enzymology and molecular biology of prokaryotic sulfite oxidation. FEMS Microbiol. Lett. 203, 1-9. doi: 10.1111/j.15746968.2001.tb10813.x

Katoh, K. (2002). MAFFT: a novel method for rapid multiple sequence alignment based on fast Fourier transform. Nucleic Acids Res. 30, 3059-3066. doi: 10.1093/nar/gkf436

Kelly, D. P., Shergill, J. K., Lu, W. P., and Wood, A. P. (1997). Oxidative metabolism of inorganic sulfur compounds by bacteria. Antonie Van Leeuwenhoek 71, 95-107. doi: 10.1023/A:1000135707181

King, G. M. (1988). Patterns of sulfate reduction and the sulfur cycle in a South Carolina salt marsh. Limnol. Oceanogr. 33, 376-390. doi: 10.4319/lo.1988.33.3.0376

Klepac-Ceraj, V., Bahr, M., Crump, B. C., Teske, A. P., Hobbie, J. E., and Polz, M. F. (2004). High overall diversity and dominance of microdiverse relationships in salt marsh sulphate-reducing bacteria. Environ. Microbiol. 6, 686-698. doi: 10.1111/j.1462-2920.2004.00600.x

Klindworth, A., Pruesse, E., Schweer, T., Peplies, J., Quast, C., Horn, M., et al. (2012). Evaluation of general 16S ribosomal RNA gene PCR primers for classical and next-generation sequencing-based diversity studies. Nucleic Acids Res. 20, 1-11. doi: 10.1093/nar/gks808

Laverman, A. M., Pallud, C., Abell, J., and Van Cappellen, P. (2012). Comparative survey of potential nitrate and sulfate reduction rates in aquatic sediments. Geochim. Cosmochim. Acta 77, 474-488. doi: 10.1016/j.gca.2011.10.033

Lee, R. W. (1999). Oxidation of sulfide by Spartina alterniflora roots. Limnol. Oceanogr. 44, 1155-1159. doi: 10.4319/lo.1999.44.4.1155 
Lenk, S., Arnds, J., Zerjatke, K., Musat, N., Amann, R., and Mussmann, M. (2011). Novel groups of Gammaproteobacteria catalyse sulfur oxidation and carbon fixation in a coastal, intertidal sediment. Environ. Microbiol. 13, 758-774. doi: 10.1111/j.1462-2920.2010.02380.x

Lenk, S., Moraru, C., Hahnke, S., Arnds, J., Richter, M., Kube, M., et al. (2012). Roseobacter clade bacteria are abundant in coastal sediments and encode a novel combination of sulfur oxidation genes. ISME J. 6, 2178-2187. doi: 10.1038/ismej.2012.66

Loy, A., Duller, S., Baranyi, C., Mussmann, M., Ott, J., Sharon, I., et al. (2009). Reverse dissimilatory sulfite reductase as phylogenetic marker for a subgroup of sulfur-oxidizing prokaryotes. Environ. Microbiol. 11, 289-299. doi: 10.1111/j.1462-2920.2008.01760.x

McDonald, D., Price, M. N., Goodrich, J., Nawrocki, E. P., DeSantis, T. Z., Probst, A., et al. (2012). An improved Greengenes taxonomy with explicit ranks for ecological and evolutionary analyses of bacteria and archaea. ISME J. 6, 610-618. doi: 10.1038/ismej.2011.139

McMurdie, P. J., and Holmes, S. (2013). phyloseq: an R package for reproducible interactive analysis and graphics of Microbiome census data. PLoS ONE 8:e61217. doi: 10.1371/journal.pone.0061217

Meyer, B., Imhoff, J. F., and Kuever, J. (2007). Molecular analysis of the distribution and phylogeny of the sox $\mathrm{B}$ gene among sulfur-oxidizing bacteria - evolution of the Sox sulfur oxidation enzyme system. Environ. Microbiol. 9, 2957-2977. doi: 10.1111/j.1462-2920.2007.01407.x

Meyer, B., and Kuever, J. (2007). Molecular analysis of the diversity of sulfatereducing and sulfur-oxidizing prokaryotes in the environment, using aprA as functional marker gene. Appl. Environ. Microbiol. 73, 7664-7679. doi: 10.1128/AEM.01272-07

Nelson, D. C., Waterbury, J. B., and Jannasch, H. W. (1982). Nitrogen fixation and nitrate utilization by marine and freshwater Beggiatoa. Arch. Microbiol. 133, 172-177. doi: 10.1007/BF00414997

Niemann, H., Linke, P., Knittel, K., Macpherson, E., Boetius, A., Brückmann, W., et al. (2013). Methane-carbon flow into the benthic food web at cold seeps a case study from the Costa Rica subduction zone. PLOS ONE 8:e74894. doi: 10.1371/journal.pone.0074894

Niering, W. A., and Warren, R. S. (1980). Vegetation patterns and processes in New England salt marshes. Bioscience 30, 301-307. doi: 10.2307/1307853

Otte, S., Kuenen, J., Nielsen, L., Paerl, H., Zopfi, J., Schulz, H., et al. (1999). Nitrogen, carbon, and sulfur metabolism in natural Thioploca samples. Appl. Environ. Microbiol. 65, 3148-3157.

Petri, R., Podgorsek, L., and Imhoff, J. F. (2001). Phylogeny and distribution of the soxB gene among thiosulfate-oxidizing bacteria. FEMS Microbiol. Lett. 197, 171-178. doi: 10.1111/j.1574-6968.2001.tb10600.x

Pezeshki, S. R., and Delaune, R. D. (1996). Responses of Spartina alterniflora and S. patens to rhizosphere oxygen deficiency. Acta Oecol. 17, 365-378.

Pott, A. S., and Dahl, C. (1998). Sirohaem sulfite reductase and other proteins encoded by genes at the $d s r$ locus of Chromatium vinosum are involved in the oxidation of intracellular sulfur. Microbiology 144, 1881-1894. doi: 10.1099/00221287-144-7-1881

Robertson, L. A., and Kuenen, J. G. (2006). “The colorless sulfur bacteria," in The Prokaryotes, eds M. Dworkin, S. Falkow, E. Rosenberg, K.-H. Schleifer, and E. Stackebrandt (New York, NY: Springer Verlag), 985-1011.

Ruby, E. G., and Jannasch, H. W. (1982). Physiological characteristics of Thiomicrospira sp. strain L-12 isolated from deep-sea hydrothermal vents. J. Bacteriol. 149, 161-165.

Sayama, M., Risgaard-Petersen, N., Nielsen, L. P., Fossing, H., and Christensen, P. B. (2005). Impact of bacterial $\mathrm{NO}_{3}^{-}$transport on sediment biogeochemistry. Appl. Environ. Microbiol. 71, 7575-7577. doi: 10.1128/AEM.71.11.7575-7577.2005
Schubauer, J. P., and Hopkinson, C. S. (1984). Above- and belowground emergent macrophyte production and turnover in a coastal marsh ecosystem, Georgia. Limnol. Oceanogr. 29, 1052-1065. doi: 10.4319/lo.1984.29. 5.1052

Segata, N., Izard, J., Waldron, L., Gevers, D., Miropolsky, L., Garrett, W. S., et al. (2011). Metagenomic biomarker discovery and explanation. Genome Biol. 12, R60. doi: 10.1186/gb-2011-12-6-r60

Sievert, S. M., Kiene, R. P., and Shulz-Vogt, H. N. (2007). The sulfur cycle. Oceanography 41, 117-123. doi: 10.5670/oceanog.2007.55

Smith, C. J., Nedwell, D. B., Dong, L. F., and Osborn, A. M. (2006). Evaluation of quantitative polymerase chain reaction-based approaches for determining gene copy and gene transcript numbers in environmental samples. Environ. Microbiol. 8, 804-815. doi: 10.1111/j.1462-2920.2005.00963.x

Sorokin, D. Y., Tourova, T. P., Galinski, E. A., Muyzer, G., and Kuenen, J. G. (2008). Thiohalorhabdus denitrificans gen. nov., sp. nov., an extremely halophilic, sulfur-oxidizing, deep-lineage gammaproteobacterium from hypersaline habitats. Int. J. Syst. Evol. Microbiol. 58, 2890-2897. doi: 10.1099/ijs.0.2008/ 000166-0

Tamura, K., Peterson, D., Peterson, N., Stecher, G., Nei, M., and Kumar, S. (2011). MEGA5: molecular evolutionary genetics analysis using maximum likelihood, evolutionary distance, and maximum parsimony methods. Mol. Biol. Evol. 28, 2731-2739. doi: 10.1093/molbev/msr121

Timmer-Ten Hoor, A. (1975). A new type of thiosulphate oxidizing, nitrate reducing microorganism: Thiomicrospira denitrificans sp. nov. Netherlands J. Sea Res. 9, 344-350. doi: 10.1016/0077-7579(75)90008-3

Tourova, T. P., Slobodova, N. V., Bumazhkin, B. K., Kolganova, T. V., Muyzer, G., and Sorokin, D. Y. (2013). Analysis of community composition of sulfuroxidizing bacteria in hypersaline and soda lakes using $\operatorname{sox} \mathrm{B}$ as a functional molecular marker. FEMS Microbiol. Ecol. 84, 280-289. doi: 10.1111/15746941.12056

Wirsen, C. O., and Jannasch, H. W. (1978). Physiological and morphological observations on Thiovulum sp. J. Bacteriol. 136, 765-774.

Wirsen, C. O., Sievert, S. M., Cavanaugh, C. M., Molyneaux, S. J., Ahmad, A., Taylor, L. T., et al. (2002). Characterization of an Autotrophic SulfideOxidizing Marine Arcobacter sp. That Produces Filamentous Sulfur. Appl. Environ. Microbiol. 68, 316-325. doi: 10.1128/AEM.68.1.316-325.2002

Ye, J., Coulouris, G., Zaretskaya, I., Cutcutache, I., Rozen, S., and Madden, T. L. (2012). Primer-BLAST: a tool to design target-specific primers for polymerase chain reaction. BMC Bioinformatics 13:134. doi: 10.1186/1471-210513-134

Conflict of Interest Statement: The authors declare that the research was conducted in the absence of any commercial or financial relationships that could be construed as a potential conflict of interest.

Received: 17 April 2014; accepted: 05 June 2014; published online: 24 June 2014. Citation: Thomas F, Giblin AE, Cardon ZG and Sievert SM (2014) Rhizosphere heterogeneity shapes abundance and activity of sulfur-oxidizing bacteria in vegetated salt marsh sediments. Front. Microbiol. 5:309. doi: 10.3389/fmicb.2014.00309

This article was submitted to Terrestrial Microbiology, a section of the journal Frontiers in Microbiology.

Copyright (c) 2014 Thomas, Giblin, Cardon and Sievert. This is an open-access article distributed under the terms of the Creative Commons Attribution License (CC BY). The use, distribution or reproduction in other forums is permitted, provided the original author(s) or licensor are credited and that the original publication in this journal is cited, in accordance with accepted academic practice. No use, distribution or reproduction is permitted which does not comply with these terms. 